American Journal of Environmental Sciences 8 (3): 322-327, 2012

ISSN 1553-345X

(C) 2012 Science Publications

\title{
Removing Boron from an Aqueous Solution Using Turmeric Extract-Aided Coagulation-Flocculation
}

\author{
${ }^{1}$ Azhar Abdul Halim, ${ }^{1}$ Nur Hanani Thaldiri, \\ ${ }^{2}$ Normah Awang and ${ }^{1}$ Mohd Talib Latif \\ ${ }^{1}$ School of Environmental and Natural Resource Sciences, \\ Faculty of Science and Technology, \\ Universiti Kebangsaan Malaysia, 43600 Bangi, Selangor, Malaysia \\ ${ }^{2}$ Environmental Health Program, Faculty of Allied Health Sciences, \\ Universiti Kebangsaan Malaysia, 50300 Kuala Lumpur, Malaysia
}

\begin{abstract}
Problem statement: Boron exists in an environment naturally either through weathering of rocks or volcanic activity but due to anthropogenic activity, boron had been distributed widely into our surroundings. Boron was a problematic pollutant due to the difficulty to remove it from the water. Turmeric which had been widely used as a spice and traditional medicine, were investigated to determine its capabilities to aid in coagulation-flocculation process to remove boron. Optimizing coagulation-flocculation process might be effective to remove boron to a lower concentration. Approach: In this study, the optimum parameter for $\mathrm{pH}$, dose of aluminium sulfate (alum) and a dose of turmeric extract were determined by conducting a set of jar test experiment. The coagulationflocculation process was performed to study the effectiveness of the turmeric extract as a coagulant aid in boron removal. Results: The result demonstrated that coagulation-flocculation process with the aid of turmeric extract can remove boron effectively at optimum conditions rather than coagulationflocculation process without the aid of turmeric extract. The optimum conditions for boron removal were achieved at $\mathrm{pH} \mathrm{7,} \mathrm{an} \mathrm{alum} \mathrm{dosage} \mathrm{of} 18,367 \mathrm{mg} \mathrm{L}^{-1}$ and turmeric extract dosage of $82 \mathrm{mg} \mathrm{L}^{-1}$. Conclusion/Recommendations: Result showed that removal of boron depends on $\mathrm{pH}$, alum dosage and turmeric extract dosage. The boron removal percentage of the aqueous solution using the coagulation-flocculation process aided by the addition of turmeric extract and without the addition of turmeric extract were 95 and $62 \%$, respectively. In addition, there was a significance difference between both processes. Turmeric extract as a coagulant aid demonstrated promising performance in boron removal and can be used as an alternative treatment to treat boron-containing wastewater.
\end{abstract}

Key words: Turmeric extract, coagulation-flocculation, boron removal

\section{INTRODUCTION}

Boron is widely distributed into our surroundings from various sources. The first element of the group IIIA on the periodic table of elements, boron is a metalloid, while the rest of the elements in group IIIA are metals. Boron does not form binary Ionic compounds and is unreactive toward both oxygen gas and water $(\mathrm{Col}$ and Col, 2003). Boron can be found in sedimentary rocks, coal, shale and some soils in the form of borates and it also exists in the environment through the rock weathering, volatilization of boric acid from seawater and volcanic eruption (Emiroglu et al., 2010). It also can enter the environment via the discharge of wastewater containing boron from anthropogenic sources and various industries (Coughlin, 1998; Howe, 1998). Boron had been used widely in various industries such as metal welding, pharmaceutical manufacture (Ozturk and Kavak, 2005), ceramic industry (Chong et al., 2009), burning wood fuel and glass products manufacture (Emiroglu et al., 2010). The concentration of boron in soil and irrigation water is normally low, however boron rapidly accumulates in soil irrigated with wastewater containing boron because of the difficulty of washing the residue out of the soil (Yilmaz et al., 2007).

Boron is an essential nutrient for plant growth but in relatively low concentration (Kabay et al., 2008). A boron deficiency in plants will result in reduced absorption of potassium, chloride and rubidium; alteration of the plasmalemma of root cells and

Corresponding Author: Azhar Abdul Halim, School of Environmental and Natural Resource Sciences, Faculty of Science and Technology, Universiti Kebangsaan Malaysia, 43600 Bangi, Selangor, Malaysia 
cessation of root growth. Lack of boron also caused abnormalities of the apical meristem, which may be a secondary effect of damage to the plant's vascular tissue (Woods, 1994). As a plant nutrient, boron can form ester borates which are important for building the cell wall structure of certain plants (Camacho-Cristobal et al., 2008). However, the boron-poisoning will occur when the amount of boron absorbed exceeds the nutritional concentration that the plant needs; a yellowish spot will appear on the leaves and the fruit of boron-poisoned plant. Drinking water containing boron is suspected to be teratogenic to human health. The concentration of boron in the drinking water that recommended by the World Health Organization (WHO) should be below $0.3 \mathrm{mg}$ boron /L (Cengeloglu et al., 2007; 2008). Later, this standard was amended to $0.5 \mathrm{mg} / \mathrm{L}$ due to the difficulty encountered in achieving the lower standard in regions with high natural levels of boron. Lately, boron had been classified as a pollutant by European Union (EU) and $1 \mathrm{mg}$ boron/L had been adopted as a standard for drinking water. Therefore, it is inevitable to devise a suitable method to remove as much boron as possible from the water.

Physiochemical and biological treatments have been used widely to remove boron from wastewater. There are several physicochemical treatment, include using ionexchange (Simonnot et al., 2000), adsorption (Alias et al., 2011), reverse osmosis (Nadav, 1999), membrane filtration (Mottez et al., 1998), electrodialysis (Kabay et al., 2008) and electrocoagulation (Yazicigil and Oztekin, 2006; Yilmaz et al., 2005; 2008). Biological treatment options include using aquatic plants such as Caulerpa Racemosa var. Cylindracea (CRC) (Bursali et al., 2009) and duckweed Lemna gibba (Marin and Oron, 2007).

Another method commonly used to treat wastewater is a coagulation-flocculation process that involves adding a coagulant such as aluminum sulfate (alum), ferric chloride or Poly-Aluminum-Chloride (PAC). This process has been found to be cost effective, less energy is needed and can be operated easily (Amuda and Alade, 2006). Coagulation acts by destabilizing the boron particle's charges. Coagulants are added to neutralize the negative charges on the colloid. Once the charge is neutralized, the small particles stick together and form microflocs which are not visible to the naked eyes. Meanwhile, flocculation will increase the size of the microflocs to form a visible floc that settles out at the end of the process. The problem with this process is that can be influenced by the nature of the water, temperature, $\mathrm{pH}$, types and dose of the coagulant used, intensity and duration of the rapid mixed (Rossini et al., 1999).
Turmeric had been applied in traditional medicine to treat jaundice and liver problem, ulcers, skin problem, cold and flu symptoms. Turmeric also can act as an antimicrobial in food preservation. The effect of the presence of Curcuma longa powder in Tamarindus indica and Garcinia atroviridis solutions was indicated by the decreasing of aluminium solubility in food preparation was reported (Halim et al., 2011a). Adsorption studies of aluminium on Curcuma longa also was carried out by Halim et al. (2011b).

Turmeric was prepared from the rhizomes of the Curcuma longa, a plant that belongs to the Zingiberaceae family (Jayaprakasha et al., 2005). Curcumin (diferuloylmethane) is an active principle of the perennial Curcuma longa herb and is the major component in turmeric. The yellow pigment of the turmeric contains curcuminoids and consists of three major constituents: Curcumin I (curcumin), Curcumin II (demethoxycurcumin) and Curcumin III (bisdemethoxycurcumin) (Goel et al., 2008). Curcumin is an acid-base indicator where at $\mathrm{pH}$ 2.5-7.0, a brilliant yellow hue will appear while a red hue will appear at $\mathrm{pH}>7.0$ (Goel et al., 2008). Rosocyanine which is a redcolored compound will form when curcumin reacts with boric acid (Akram et al., 2010). In acidic solutions, a 2:1 curcumin-acid boric complex will form. Curcumin also can be classified as a chelating agent due to the present of 1,3-diketone structure. The aim of this study is to investigate the feasibility of removing boron from an aqueous solution by the alum coagulation-flocculation process, aided by the addition of curcuma longa extract.

\section{MATERIALS AND METHODS}

The boric acid solution $\left(50 \mathrm{mg} \mathrm{L}^{-1}\right)$ and alum $\left(100,000 \mathrm{mg} \mathrm{L}^{-1}\right)$ was prepared. The turmeric extract was prepared from fresh turmeric. Sodium hydroxide $(\mathrm{NaOH})$ and hydrochloric acid $(\mathrm{HCl})$ were added to the solution to adjust the $\mathrm{pH}$. The Carmine method, adapted from the Standard Methods for the Examination of Water and Wastewater (Eaton and Franson, 2005) was used to determine the actual concentration of boron between the detection limits of $0.2-14.0 \mathrm{mg} \mathrm{L}^{-1}$. Optimum parameters such as the $\mathrm{pH}$ of the mixture, the dose of alum and the dose of turmeric extract were determined in order to maximize the coagulation-flocculation process.

A jar test was performed with 1 min of the rapid mix at $80 \mathrm{rpm}, 30 \mathrm{~min}$ of slow mix at $20 \mathrm{rpm}$ and 30 min of settling period. The data were collected and the test was repeated three times.

Optimum pH: The range of $\mathrm{pH}$ that was chosen for this study ranged from 6.0 - 11.0. Six beakers $(n=6)$ with 400 
$\mathrm{mL}$ of boron solution were prepared. $90 \mathrm{~mL}$ of alum solution was added to each beaker. In the coagulationflocculation process aided by turmeric extract, $5 \mathrm{~mL}$ of turmeric extract was added to each beaker. After a $30 \mathrm{~min}$ settling period, the final concentration of boron from each beaker will be determined.

The optimum dose of alum: A jar test was performed by varying the dose of alum within a range from 50-100 mL. Six beakers $(n=6)$ with $400 \mathrm{~mL}$ of a $\mathrm{pH} 7$ boron solution were prepared. In the coagulation-flocculation process with the aid of turmeric extract, $5 \mathrm{~mL}$ of turmeric extract was added in each beaker. After a 30 min settling period, the final concentration of boron from each beaker will be determined.

The optimum dose of turmeric extract: Six beakers $(n=6)$ with $400 \mathrm{~mL}$ of boron solution were prepared. The turmeric extract that was added to each beaker ranged from 2-12 $\mathrm{mL}$. The $\mathrm{pH}$ of the boron solution was adjusted to achieve $\mathrm{pH} 7$ and then $90 \mathrm{~mL}$ of alum was added to each beaker. After a 30 min settling period, the final concentration of boron from each beaker will be determined.

\section{RESULTS}

The percentage of boron removed and the optimum parameters of coagulation-flocculation process with and without the aid of turmeric extract have been compared in this study.



Fig. 1: Effect of $\mathrm{pH}$ on the effectiveness of removing boron
The effect of the $\mathbf{p H}$ : The optimum $\mathrm{pH}$ of the coagulation-flocculation process with and without the aid of the turmeric extract was $\mathrm{pH} 7$ and $\mathrm{pH} 10$, respectively. The result demonstrated that percentage of boron removed was $88 \%$ for $\mathrm{pH} 7$ (with turmeric extract added) and $63 \%$ for $\mathrm{pH} 10$ (without the addition of turmeric), as shown in Fig. 1.

The effect of the dose of alum: Optimum dose of alum to remove boron using the coagulation-flocculation process with and without the aid of turmeric extract was $18367 \mathrm{mg} \mathrm{L}^{-1}$; the percentage of boron removed was 76 and $73 \%$, respectively, as shown in Fig. 2.

The effect of the dose of turmeric extract: The optimum dose of turmeric extract obtained from coagulation-flocculation process to remove boron was $82 \mathrm{mg} \mathrm{L}^{-1}$, where the percentage of boron removed was $80 \%$, as shown in Fig. 3.

Comparison between the coagulation-flocculation process with and without the aids of turmeric extract: By applying the optimum parameters that had

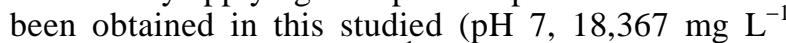
dose of alum and $82 \mathrm{mg} \mathrm{L}^{-1}$ dose of turmeric extract), we had compared the boron removal between coagulation-flocculation process with and without the addition of turmeric extract. The result had demonstrated as stated in the Table 1.

Table 1: The comparison between results from the coagulationflocculation process with and without the assistance of turmeric extract

\begin{tabular}{lll}
\hline & $\begin{array}{l}\text { With the addition of } \\
\text { turmeric extract }\end{array}$ & $\begin{array}{l}\text { Without the addition } \\
\text { of turmeric extract }\end{array}$ \\
\hline $\begin{array}{l}\text { Mean of percentage of } \\
\text { boron removed }\end{array}$ & $95 \%$ & $62 \%$ \\
$\begin{array}{l}\text { Optimum parameters: } \\
\mathrm{pH}\end{array}$ & $\mathrm{pH} 7$ & $\mathrm{pH} 7$ \\
$\begin{array}{l}\text { Dose of alum } \\
\text { Dose of turmeric extract }\end{array}$ & $18,367 \mathrm{mg} \mathrm{L}^{-1}$ & $18,367 \mathrm{mgL}^{-1}$ \\
\hline
\end{tabular}

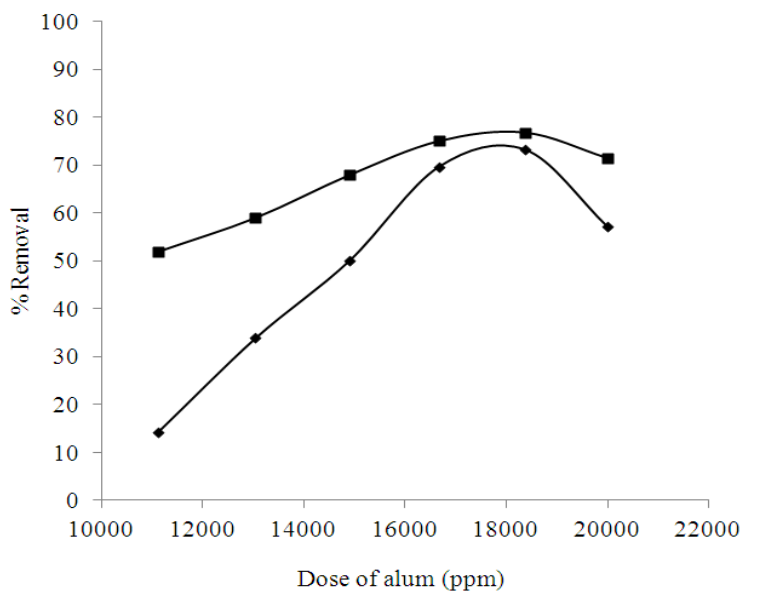

Fig. 2: Effect of the size of the dose of alum on the effectiveness of removing boron 


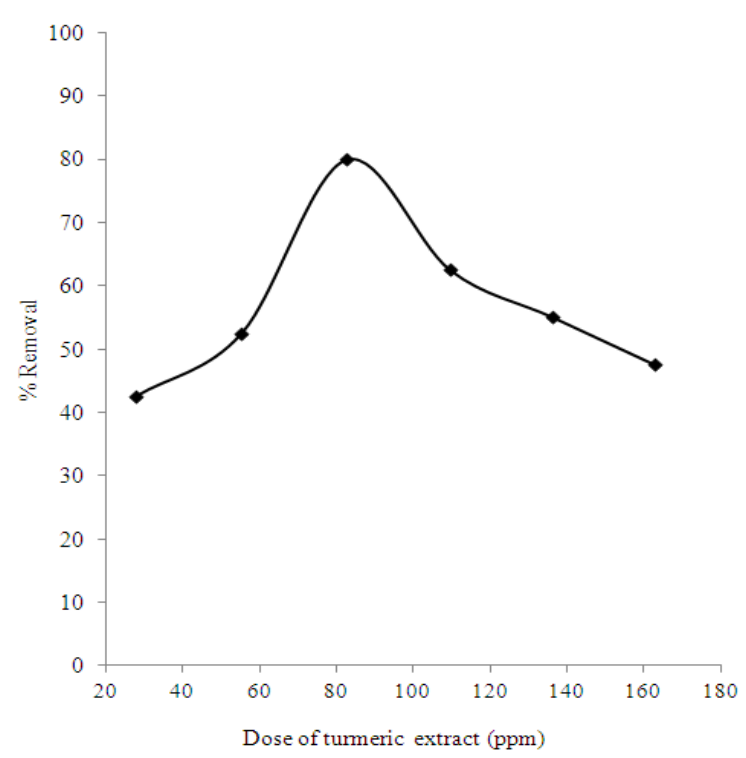

Fig. 3: Effect of the size of the dose of turmeric extract on the effectiveness of removing boron

\section{DISCUSSION}

The percentage of boron removed and the optimum parameters of coagulation-flocculation process with and without the aid of turmeric extract had been compared and discussed in this study.

The effect of the $\mathbf{p H}$ : The $\mathrm{pH}$ level is one of the important factors that affect the performance of the coagulation-flocculation process (Ayguna and Yilmaz, 2010) since it controls the hydrolysis species (Camacho-Cristobal et al., 2008). However, different coagulants will have different zones of $\mathrm{pH}$ where the coagulant will become more effective in removing the colloidal particle and producing a good coagulationflocculation process. For an example, alum will become more effective when the solution falls within the $\mathrm{pH}$ range from 6.5-7.5.

The effect of the dose of alum: Aluminum-based and ferric-based hydrolyzing metal salts are widely used as coagulants in the treatment of water (Gregory and Duan, 2001). In this study, alum was added to the water and formed aluminum hydroxide floc, a gelatinous precipitate. By adding alum to the solution, positively charged aluminum hydroxide formed and neutralized the negative charges of the particles in the solution, thus reducing the electrostatic force between particles. When the electrostatic force was reduced, the particles agglomerated and formed a larger floc that was easily removed from water.

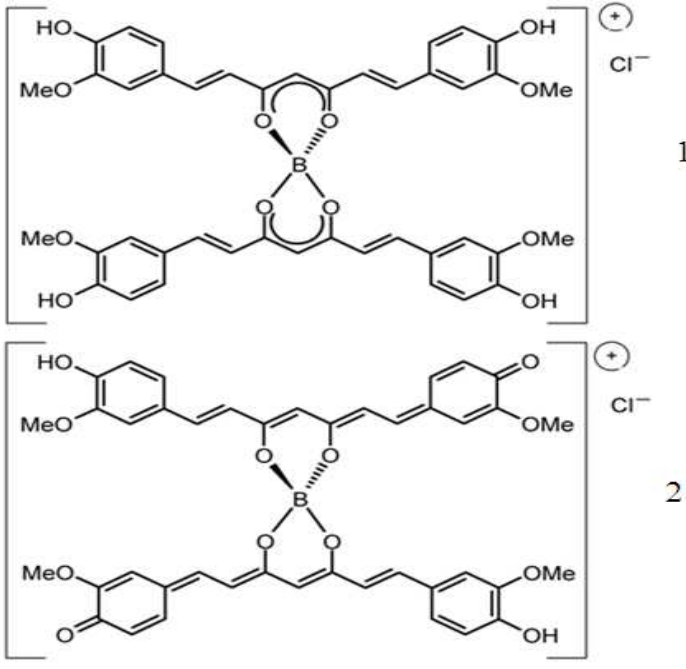

Fig. 4: Structure of the curcumin-boron complex (rosocyanine)

In this studied, there was a slightly different in the percentage of boron removal which might due to the addition of the turmeric extract in the process.

Effect of the dose of turmeric extract: In this study, turmeric extract was used as an aid to the coagulant. By enhancing the agglomeration of the particle to form a larger and heavier floc, the turmeric extract increased the percentage of boron removed. Curcumin, which is one of the constituents in turmeric, can react with the boron in the solution to form a curcumin-boron complex that is known as rosocyanine, as shown in the Fig. 4.

Comparison between the coagulation-flocculation process with and without the aids of turmeric extract: Comparison of the coagulation-flocculation process with and without the aid of turmeric extract had been studied and by using statistical analysis where an independent T-test had been applied, the result showed that the $p$ value was less than $0.05(\mathrm{p}<0.05)$. Thus, there was a significant difference between the coagulationflocculation process with and without the aid of turmeric extract, where the percentage of boron removed was 95 and 62\%, respectively (as shown in Table 1). The coagulation-flocculation process with the aid of the turmeric extract removed the highest percentage of boron, due to the production of the curcumin-boron complex that known as rosocyanine, thus increasing the removal of boron.

\section{CONCLUSION}

Optimum parameter determined in this study was $\mathrm{pH} \mathrm{7,} \mathrm{the} \mathrm{dose} \mathrm{of} \mathrm{alum} \mathrm{at} 18,367 \mathrm{mg} \mathrm{L}^{-1}$ and dose of 


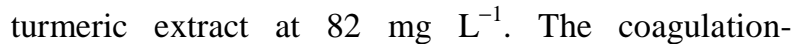
flocculation process, aided by the addition of turmeric extract, removed a higher percentage of boron than the coagulation-flocculation process without the addition of turmeric extract. The mean of the percentages of boron removed were 95 and $62 \%$, respectively.

\section{ACKNOWLEDGEMENT}

The researcher is grateful to the National University of Malaysia for providing sufficient facilities and funding while the research was being carried out.

\section{REFERENCES}

Akram, M., Shahab-Uddin, A. Ahmed, K. Usmanghani and $\mathrm{f}$ A. Hannan et al., 2010. Curcuma longa and curcumin: A review article. Rom. J. Biol. Plant Biol., 55: 65-70.

Alias, N.H.M., A.A. Halim and M.I.A. Wahab, 2011. Boron removal from aqueous solutions using composite adsorbent based on carbon-mineral. Sains Malaysiana, 40: 1271-1276.

Amuda, O.S. and A. Alade, 2006. Coagulation/flocculation process in the treatment of abattoir wastewater. Desalination, 196: 22-31. DOI: 10.1016/j.desal.2005.10.039

Ayguna, A. and T. Yilmaz, 2010. Improvement of coagulation-flocculation process for treatment of detergent wastewaters using coagulant aids. Int. J. Chem. Environ. Eng., 1: 1-5.

Bursali, E.A., L. Cavas, Y. Seki, S.S. Bozkurt and M. Yurdakoc, 2009. Sorption of boron by invasive marine seaweed: Caulerpa racemosa var. cylindracea. Chem. Eng. J., 150: 385-390. DOI: 10.1016/j.cej. 2009.01.016

Camacho-Cristobal, J.J., J. Rexach and A. GonzálezFontes, 2008. Boron in plants: Deficiency and toxicity. J. Integrative Plant Biol., 50: 1247-1255. DOI: 10.1111/j.1744-7909.2008.00742.X

Cengeloglu, Y., A. Tor, G. Arslan, M. Ersoz and S. Gezgin, 2007. Removal of boron from aqueous solution by using neutralized red mud. J. Hazardous Mater., 142: 412-417. DOI: 10.1016/j.jhazmat. 2006.08.037

Cengeloglu, Y., G. Arslan, A. Tor, I. Kocak and N. Dursun, 2008. Removal of boron from water by using reverse osmosis. Separation Purification Technol., 64: 141-146. DOI: 10.1016/j.seppur. 2008.09.006
Chong, M.F., K.P. Lee, H.J. Chieng and I.I.S. Ramli, 2009. Removal of boron from ceramic industrial wastewater by adsorption-flocculation mechanism using Palm Oil Mill Boiler (POMB) bottom ash and polymer. Water Res., 43: 3326-3334. DOI: 10.1016/j.watres. 2009.04.044

Col, M. and C. Col, 2003. Environmental boron contamination in waters of Hisarcik area in the Kutahya Province of Turkey. Food Chem. Toxicol., 41: 1417-1420. DOI: 10.1016/S02786915 (03)00160-1

Coughlin, J.R., 1998. Sources of human exposure. Bio. Trace Element Res., 66: 87-100. DOI: 10.1007/BF02783129

Eaton, A.D. and M.A.H. Franson, 2005. Standard Methods for the Examination of Water and Wastewater. 21st Edn., American Public Health Association, Washington, DC., ISBN-10: 0875530478, pp: 1200.

Emiroglu, O., A. Cicek, N. Arslan, S. Aksan and M. Ruzgar, 2010. Boron concentration in water, sediment and different organisms around large borate deposits of Turkey. Bull. Environ. Contamination Toxicol., 84: 427-431. DOI: 10.1007/S00128-010-9961-8

Goel, A., A.B. Kunnumakkara and B.B. Aggarwal, 2008. Curcumin as "Curecumin": From kitchen to clinic. Biochem. Pharmacol., 75: 787-809. DOI: 10.1016/j.bcp.2007.08.016

Gregory, J. and J. Duan, 2001. Hydrolyzing metal salts as coagulants. Pure Applied Chem., 73: 2017-2026.

Halim, A.A., E. Ezani, M.S. Othman, N. Awang and M. Ikram et al., 2011a. Adsorption studies of aluminium onto curcuma Longa. Aus. J. Basic Applied Sci., 5: 1170-1177.

Halim, A.A., F.A. Bakar, N.Z. Abidin, N. Awang and M.I. Wahab et al., 2011b. Effect of the acidic food flavors and turmeric towards aluminium leachability. Aus. J. Basic Applied Sci., 5: 597-601.

Howe, P.D., 1998. A review of boron effects in the environment. Bio. Trace Element Res., 66: 153166. DOI: $10.1007 / \mathrm{BF} 02783135$

Jayaprakasha, G.K., L.J.M. Rao and K.K. Sakariah, 2005. Chemistry and biological activities of $C$. longa. Trends Food Sci. Technol., 16: 533-548. DOI: 10.1016/j.tifs.2005.08.006

Kabay, N., O. Arar, F. Acar, A. Ghazal and U. Yuksel et al., 2008. Removal of boron from water by electrolysis: Effect of feed characteristics and interfering ions. Desalination, 223: 63-72. DOI: 10.1016/j.desal.2007.01.207 
Marin, C.M.D.C. and G. Oron, 2007. Boron removal by the duckweed Lemna gibba: A potential method for the remediation of boron-polluted waters. Water Res., 41: 4579-4584. DOI: 10.1016/j.watres.2007.06.051

Mottez, F., J.C. Adam, A. Heron, S. Kasthurirengan and A. Hofmann et al., 1998. Development of boron reduction system for sea water desalination. Desalination, 118: 25-33. DOI: 10.1016/S00119164 (98)00076-9

Nadav, N., 1999. Boron removal from seawater reverse osmosis permeate utilizing selective ion exchange resin. Desalination, 124: 131-135. DOI: 10.1016/S0011-9164(99)00097-1

Ozturk, N. and D. Kavak, 2005. Adsorption of boron from aqueous solutions using fly ash: Batch and column studies. J. Hazard. Mater., 127: 81-88. DOI: 10.1016/j. jhazmat. 2005.06.026

Rossini, M., J.G. Garrido and M. Galluzzo, 1999. Optimization of the coagulation-flocculation treatment: Influence of rapid mix parameters. Water Res., 33: 1817-1826. DOI: 10.1016/S00431354 (98)00367-4

Simonnot, M.O., C. Castel, M. Nicolai, C. Rosin and M. Sardin et al., 2000. Boron removal from drinking water with a boron selective resin. Water Res., 34: 109-116. DOI: 10.1016/S0043-1354 (99)00130-X
Woods, W.G., 1994. An introduction to boron: History, sources, uses and chemistry. Environ. Health Perspectives, 102: 5-11. PMID: 7889881

Yazicigil, Z. and Y. Oztekin, 2006. Boron removal by electrolysis with anion-exchange membranes. Desalination, $\quad 190$ : 71-78. DOI: 10.1016/j.desal.2005.07.016

Yilmaz, A.E., R. Boncukcuoglu and M. M. Kocakerim, 2007. A quantitative comparison between electrocoagulation and chemical coagulation for boron removal from boron-containing solution. J. Hazardous Mater., 149: 475-481. DOI: 10.1016/j. jhazmat. 2007.04.018

Yilmaz, A.E., R. Boncukcuoglu, M.M. Kocakerim and B. Keskinler, 2005. The investigation of parameters affecting boron removal by electrocoagulation method. J. Hazard. Mater., 125: 160-165. DOI: 10.1016/j. jhazmat. 2005.05.020

Yilmaz, A.E., R. Boncukcuoglu, M.M. Kocakerim, M.T. Yilmaz and C. Paluluoglu, 2008. Boron removal from geothermal waters by electrocoagulation. J. Hazard. Mater., 153: 146151. DOI: 10.1016/j. jhazmat. 2007.08.030 